\title{
Identification of the stages of ovarian maturation of the Argentine hake Merluccius hubbsi Marini, 1933 (Teleostei: Merlucciidae): advantages and disadvantages of the use of the macroscopic and microscopic scales
}

\author{
Renato M. Honji*, André M. Vaz-dos-Santos** \\ and Carmen Lúcia D. B. Rossi-Wongtschowski***
}

\begin{abstract}
The Argentine hake Merluccius hubbsi is a demersal-pelagic species on which few studies have been undertaken, despite its importance for the fisheries of the South-Southeastern Brazilian region, The species is the most important commercial fishery resource in Uruguay and Argentina, where several studies have permitted the proper monitoring of the species. The ovarian maturation of the Argentine hake is analysed in this study. A scale of maturation is presented in the light of the oocyte development and the use of macro and microscopic scales of ovarian maturation are compared. It was detected that the oocyte types and derived structures present in the ovaries are similar to those already described both for the species and for teleosts in general; group synchronous development and multiple spawning are typical. The identification of ovarian maturation based only on external morphological characteristics of the gonads presents many errors, mainly in the characterization of the stages of maturation, which makes imperative the parallel analysis of the oocyte development, undertaken through histological ovarian cross-sections.
\end{abstract}

A merluza Merluccius hubbsi é uma espécie demerso-pelágica sobre a qual, apesar de sua importância nas pescarias da Região Sudeste-Sul do Brasil, poucos estudos foram realizados. Neste aspecto, destacam-se o Uruguai e a Argentina, países onde ela é o principal recurso pesqueiro e onde a existência de inúmeros estudos tem permitido o monitoramento da espécie. Neste estudo a maturação ovariana da merluza é analisada. Através do desenvolvimento ovocitário, apresenta-se uma escala de maturação e compara-se o emprego de escalas macro e microscópicas de maturação dos ovários. Constatou-se que os tipos de ovócitos e estruturas derivadas presentes nos ovários são semelhantes aos já descritos para a espécie e para teleósteos; o desenvolvimento dos ovócitos é sincrônico em grupos e a desova é parcelada. A identificação da maturação ovariana com base apenas em características morfológicas externas das gônadas apresenta muitos erros, principalmente na caracterização do estádio em maturação, sendo imprescindível a análise paralela do desenvolvimento ovocitário, realizada através de cortes histológicos dos ovários.

Key words: Ovarian development, Histology, Reproduction, Brazil.

\section{Introduction}

The Argentine hake Merluccius hubbsi Marini, 1933 is a demersal-pelagic species found only on the western coast of the South Atlantic, from the south of the State of Espírito Santo to the south of Argentina (Figueiredo \& Menezes, 1978; Figueiredo et al., 2002; Cousseau \& Perrotta, 2004; Vaz-dos-Santos \& Rossi-
Wongtschowski, 2005). In terms of commercial fisheries, it is the most important species in both Argentina and Uruguay (Rey \& Arena, 1999; Aubuone et al., 2000) and has been intensively studied and monitored in those countries, since Angelescu et al. (1958) to the more recent contributions of Rey \& Arena (op. cit.), Bezzi et al. (2000a,b), Bezzi \& Ibañez(2003), Lorenzo (2003), Bezzi \& Tringali (2003), Sabatini (2004) and Pájaro et al. (2005).

*Programa REVIZEE / Instituto Oceanográfico da Universidade de São Paulo (IOUSP), Praça do Oceanográfico, 191 sala 103A, CEP 05508-120 São Paulo, SP, Brazil. e-mail: honjijp@usp.br

**Instituto Oceanográfico da Universidade de São Paulo (IOUSP) / Universidade Santa Cecília (UNISANTA), Curso de Biologia Marinha, Rua Oswaldo Cruz, 266 sala B1, CEP 11045-900 Santos, SP, Brazil. e-mail: amvaz@usp.br / andre@unisanta.br

***Instituto Oceanográfico da Universidade de São Paulo (IOUSP), Praça do Oceanográfico, 191 sala 103A, CEP 05508-120 São Paulo, SP, Brazil. e-mail: cwongski@usp.br 
In Brazil, Vaz-dos-Santos \& Rossi-Wongtschowski (2005) refer that the capture of the Argentine hake was only sporadic until 2001, when it became the target of the trawling fleets operating at greater depths. Further, those authors realized that only Torres-Pereira (1983), Haimovici et al. (1993) and Vaz-dos-Santos (2002) had turned their attention to the species, analysing the distribution of eggs and larvae in Rio Grande do Sul State, the feeding and reproduction also in Rio Grande do Sul and the growth in the South-Southeastern Atlantic, respectively.

In view of the increase in the size of the captures and the lack of information that would permit the management of the species, Vaz-dos-Santos \& Rossi-Wongtschowski (2005) presented an analysis of its fishery in Brazil, based on the first studies of Argentine hake population dynamic.

Reproduction is an essential aspect of the understanding of the biology of any species and, in the case of the fisheries, of the stock replacement. Among the various aspects regarding the studies of fish reproduction, Vazzoler (1996) draws attention to the identification of the gonads maturation as the step subsequent to the identification of the sex, which is the first step in any reproductive study. West (1990) points out that the identification of the reproductive cycle of a species is made by classifying the development of the gonads. Guerra \& Sánchez (1998) point to the study of the development of the reproductive apparatus (that is to say, of the maturation of the gonads) as an essential item for the identification of reproductive seasons and areas, of the achievement of the first gonads maturation and of fecundity. Those authors consider, further, that the majority of reproduction studies give priority to females analysis of the ovary development takes longer than that of the testicle.

The identification of the ovarian maturation stages may be done macroscopically, based on visual characters such as changes of size, colouring, aspects of the oocytes and irrigation. Microscopically, they are made taking into consideration ovary cytological characteristics (West, 1990; Vazzoler, 1996). Christiansen et al. (1973), West (op. cit.) and Dias et al. (1998) emphasize that the characterization of the oocyte development of any species takes the greatest importance because, at times, the changes observed macroscopically do not sufficiently well reflect the biological events that are taking place in the interior of the gonad. It is for this reason that the histological analysis of the ovaries permits a more precise assessment of the reproductive parameters of bony fish, since the method is more accurate (Hunter \& Macewicz, 1985).

In both Argentina and Uruguay, according to the various studies of Merluccius hubbsi, gonadal maturation and oocyte development have been analysed specially by Ciechomski (1967), Christiansen (1971), Christiansen \& Cousseau (1971), Christiansen et al. (1986), Grunwaldt (1986), Olivieri \& Christiansen (1987), Louge \& Christiansen (1992, 1993), Portela et al. (1994) and Louge (1996). Among these, Christiansen \& Cousseau (op. cit.) deserve special mention as presenting the scale of gonadal maturation traditionally used for the hake in Argentina.
This study has sought to characterize the oocyte development of M. hubbsi in the South-Southeast of Brazil, providing a precise scale of ovarian maturation.

\section{Material and Methods}

The material used in this study was provided by fishing prospection cruises (mid-water trawls, otter trawls and longline) undertaken during the fishing season yearly from 1996 to 2002 between São Tomé Cape (RJ, 22 $\left.{ }^{\circ} \mathrm{S}\right)$ and the Arroio Chuí (RS, $\left.34^{\circ} \mathrm{S}\right)$. At the same time, samples were also obtained from the fishing fleets of Santos and Guarujá (Fig. 1).

The Argentine hake obtained were taken to the laboratory for sizing (total length $\mathrm{L}_{\mathrm{t}}$ in milimeters) and weighing (total weight $\mathrm{W}_{\mathrm{t}}$ in grams). Identification of sex was in accordance with Vazzoler (1996).

A priori the stages of ovarian maturation were identified by the naked eye, using the Vazzoler (1996) scale: stage A immature, stage $\mathrm{B}$ - maturing, stage $\mathrm{C}$ - mature and stage $\mathrm{D}$ spent. As the resting stage is morphologically similar to stage B (maturing), it has been included in this latter. Where there was doubt, the gonadal maturation was recorded as NI (not identified). The maturation scales of the Argentine hake have not been used (apart form that of Christiansen \& Cousseau, 1971) because all are based on the oocyte characteristics.

After this procedure, the ovaries were removed and weighed on an analytical balance, accurate to the nearest thousandth of a gram ( $\mathrm{W}_{\mathrm{g}}$ in grams), later being fixed in formalin $10 \%$ for 15 days and then conserved in alcohol $70 \%$ (Vazzoler, 1996).

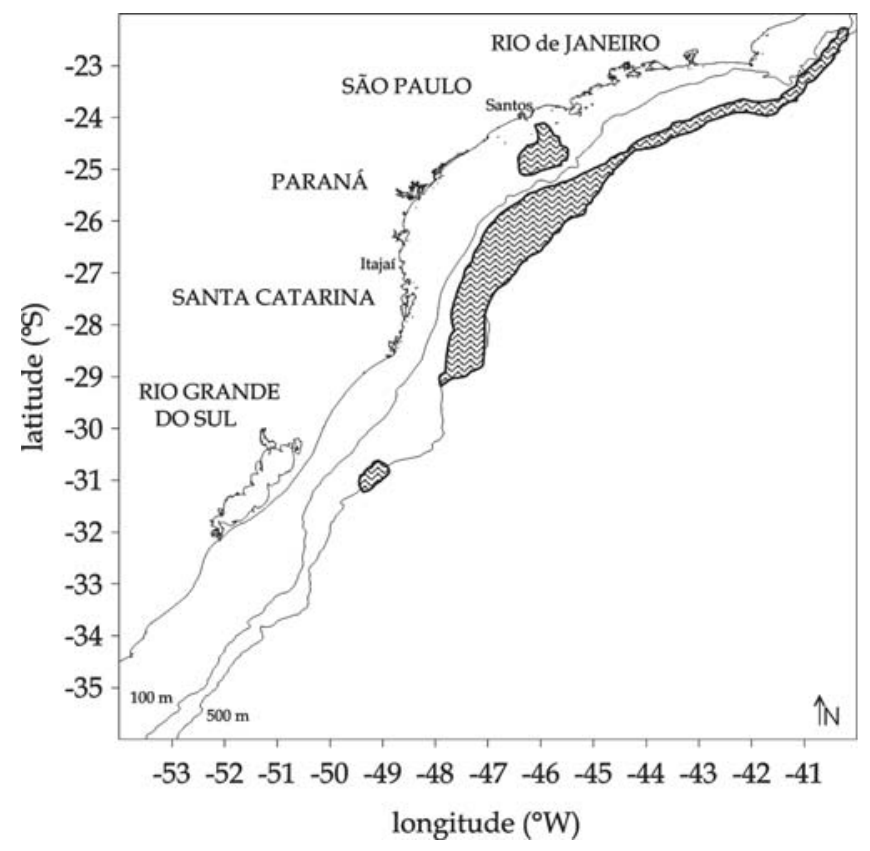

Fig. 1. Merluccius hubbsi: area of collection of samples obtained during surveys and the operations of the commercial fishing fleet of Santos and Guarujá in the period from 1996 to 2002. 
Table 1. Merluccius hubbsi: classification of ovarian maturation stage based on oocyte phase of development (+ current; ++ frequent; +++ predominant).

\begin{tabular}{ccccccc}
\hline $\begin{array}{c}\text { Ovarian } \\
\text { Stages }\end{array}$ & \multicolumn{5}{c}{ Oocyte phase of development } & \multicolumn{3}{c}{ Postovulatory } \\
& I & II & III & IV & V & follicles \\
\hline A & + & +++ & ----- & ---- & ----- & ----- \\
B & + & ++ & +++ & + & ---- & ---- \\
C & + & ++ & ++ & +++ & + & ---- \\
D & + & ++ & + & ++ & +++ & + \\
E & + & +++ & + & + & ++ & +++ \\
\hline
\end{tabular}

Twenty ovaries for each stage of maturation and for each group of total length class were selected for the preparation of the histological cross-sections. A transversal slice of about $5 \mathrm{~mm}$ thickness was removed from this material, from the centre of the lobe of the ovary, the most uniform lobe being chosen, with no ruptures and that had not been deformed by the conservation process. From larger ovaries, due to the diameter of the lobe being greater than the area of the blade, only a portion of this transversal slice was removed, from the centre to the edge. The material was then sent to the Histopathological Laboratory of the Faculty of Veterinary Medicine and Zootechnology of the University of São Paulo (FMVZ-USP) for the preparation of ovarian permanent histological cross-sections, with hematoxylin-eosin (HE) staining. All fixed ovaries and histological slices are preserved in the collection of the Laboratório de Ictiofauna, Instituto Oceanográfico da Universidade de São Paulo (from MEHU 000001/0 until MEHU 569222/3).

The histological slices were analysed under the microscope with transmitted light and magnification of 40x. Two analyses were carried out by one and the same reader and these were checked by another reader. The different phases of the oocyte development were analysed and described on the basis of the studies of Christiansen (1971), West (1990), Vazzoler (1996), Grier (2000) and Patiño \& Sullivan (2002), care being taken to observe typical gonadal characteristics of the species. For the identification of the postovulatory follicles Hunter \& Goldberg (1980), Olivieri \& Christiansen (1987) and Cornejo (1998) were also taken into consideration as were Hunter \& Macewicz (1985) for the atretic follicles.

On the basis of these results, Christiansen \& Cousseau (1971), West (1990), Louge \& Christiansen (1992) and Vazzoler (1996) and the criteria given in Table 1, adapted from Dias et al. (1998), a maturation scale for the ovary of the Argentine hake was draw up. This scale, which took into consideration the frequency and predominance of the various types of oocytes and derived structures (postovulatory and atretic follicles), enabled the authors to correct the classification of the stages of maturation used a priori.

The results of the macro and microscopic assessments were compared and discussed, and are here presented.

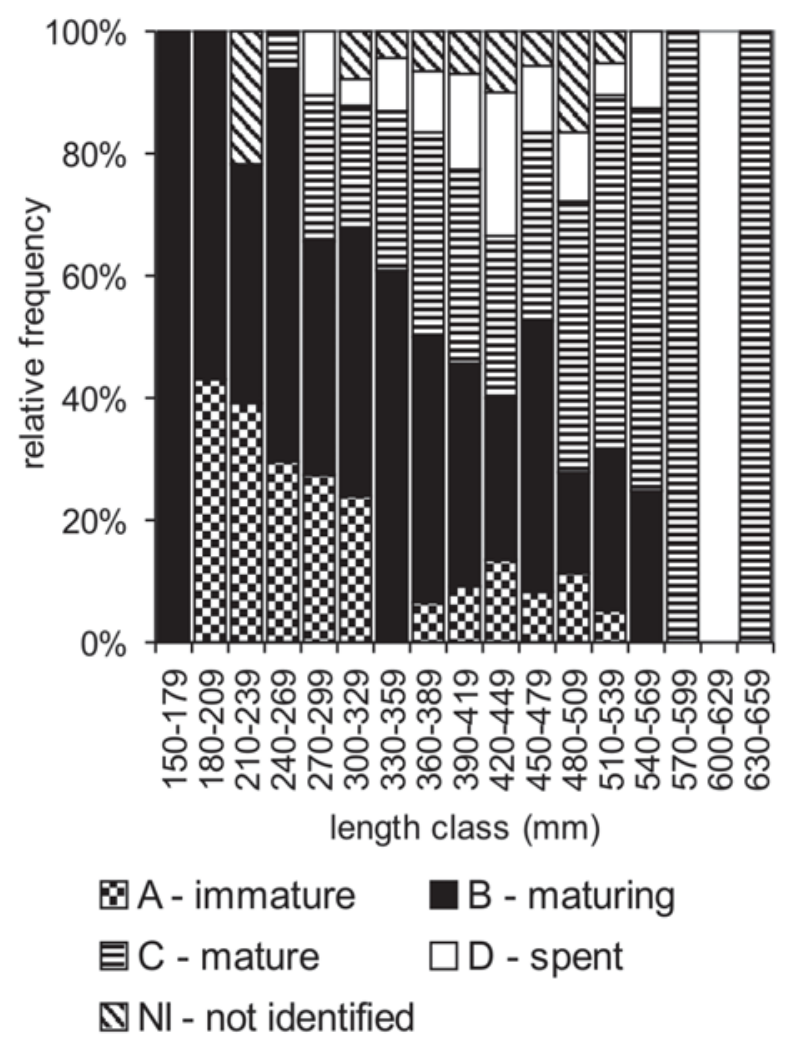

Fig. 2. Merluccius hubbsi: relative frequency of females by stage of gonadal maturation identified macroscopically by class of total lenght $(n=326)$.

\section{Results}

Of the total number collected, 326 ovaries were selected (females length ranging between 164 and $647 \mathrm{~mm}$; average $376 \mathrm{~mm}$ ) for the preparation of histological cross-sections. Figure 2 gives the frequency of individuals by total length class and stages of gonadal maturation attributed a priori, simply on the basis of the macroscopic characteristics.

The following phases of oocyte development were identified based on the analysis of the histological cross-sections:

Phase I - Oocytes with chromatin nucleolar and/or perinucleolar (young germinative cells and oocytes of the storage stock) - these kinds of cells indicate the beginning of the development of the oocytes and can appear gathered in nests, set in the ovarian lamella; their cytoplasm is thin and the nucleus rounded, being intensively basophilic and generally presenting a single nucleolus in a central position (nucleolar chromatin); some oocytes present a slight increase in volume, due to the beginning of the absorption of substances; the nucleus increases in size and the nucleoli become more numerous and migrate to the edge of the nucleus; one characteristic of these oocytes is that the cytoplasm is intensively basophilic (perinucleolar) (Fig. 3); 


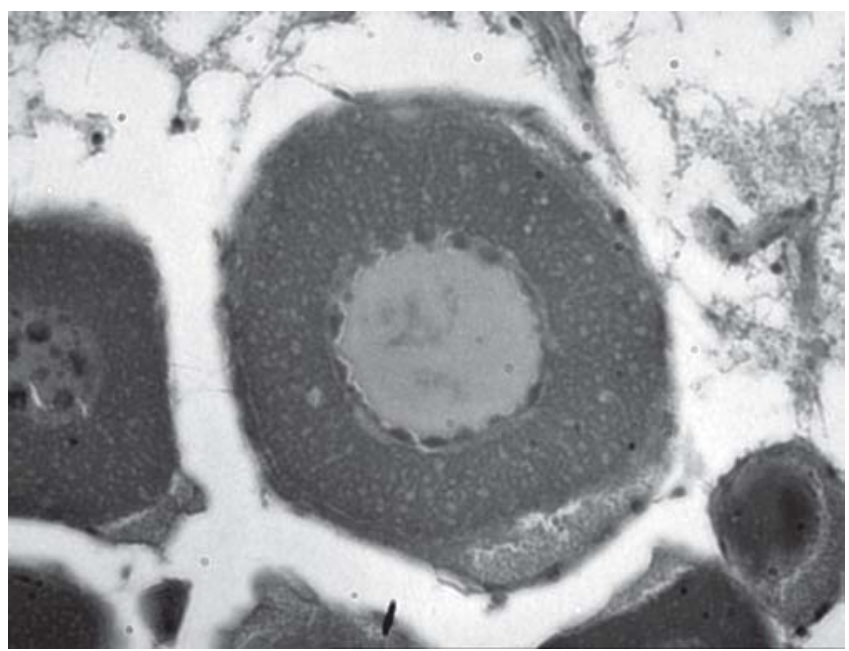

Fig. 3. Merluccius hubbsi: oocyte in perinucleolar stage (center) $(0.16 \mathrm{~mm}$ length field).

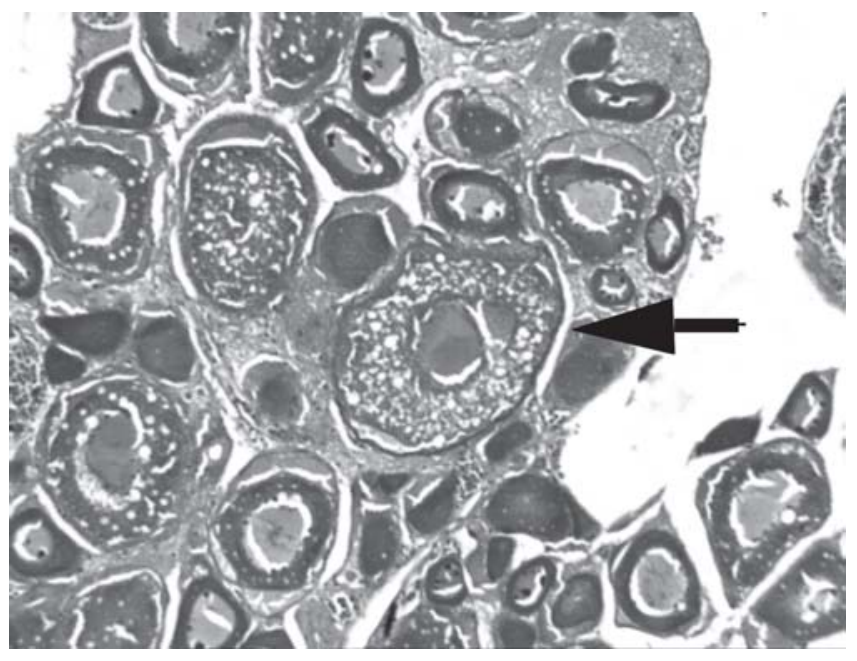

Fig. 4. Merluccius hubbsi: oocyte in cortical alveolar stage (arrow) ( $1.5 \mathrm{~mm}$ length field).

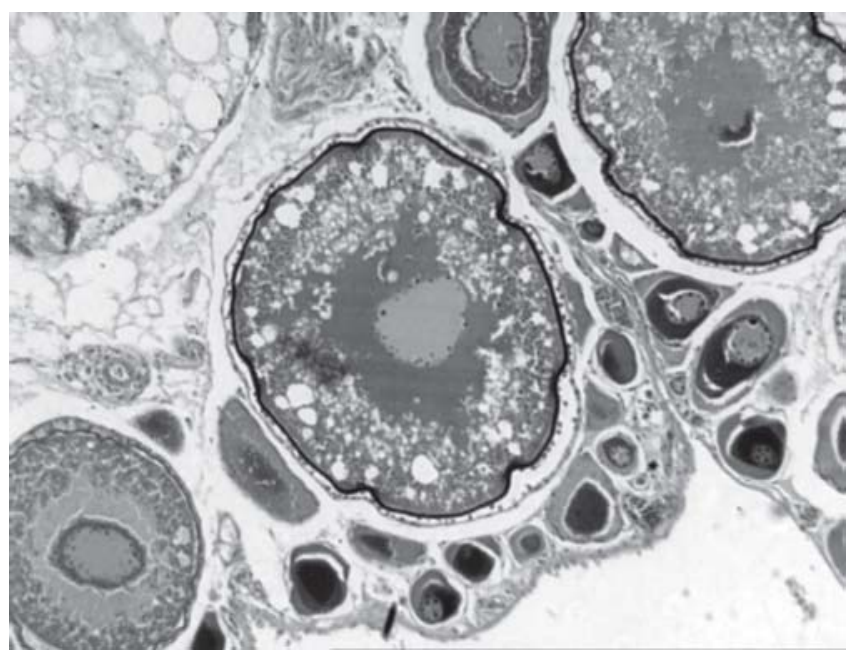

Fig. 5. Merluccius hubbsi: oocyte with lipidic and proteic vitellogenesis (1.5mm length field).
Phase II - Oocytes with cortical alveoli - present clear vacuolisation in the cytoplasm; these vitellinic vesicles appear in the cytoplasm of the cells as empty spheres, as a result of the HE staining (these chemicals have no affinity with the material present in these vesicles). The larger part of these structures is situated near the cell membrane. Its contents are discharged into the perivitelline space after fertilization and also help eggs to float; it is the phase when the chorion appears (Fig. 4);

Phase III - Oocytes with lipid and protein vitellogenesis characterized by the presence of lipid vesicles and the deposit of protein granules; this deposit, in the shape of acidophilic granules, generally first appear from the border of the cytoplasm, thus indicating the beginning of this phase (Fig. 5); Phase IV - Oocytes with complete vitellogenesis - the predominance of lipid vesicles is not seen, the oocyte increases in size, due to the growing acceleration of the number of granules of acidophilic vitellin (proteinic), giving the cytoplasm the appearance of a mosaic. The basophilia disappears almost completely (Fig. 6);

Phase V - Oocytes with nucleus migration and/or hydration - this phase is characterized by the migration of the nucleus to the edge of the cytoplasm towards the micropyle (the orifice situated in the oocyte membrane through which the spermatozoid penetrates) (Fig. 7); the oocytes undergoing hydration are pink in colour and are characterized by the hydration of the cytoplasm, which leads to the coalescence of the yolk granules. There is, further, a marked increase in the oocytes volume.

Beyond these phases of oocyte development described, it was possible to identify two other structures:

Postovulatory follicles - the follicular membrane remains in the ovary after the liberation of the oocytes into the surrounding medium, tending to collapse due to the mechanical pressure. They appear as shrinkage and distorted structures with no cells in their lumen (initially) and are present during the period of spawning (Fig. 8);

Atretic follicles - these consist of oocytes which, for some reason (whether environmental or physiological), are being absorbed by the organism. All the structures which constitute an ovarian follicle (external theca, internal theca, follicular cells, chorion and oocytes) will be absorbed. The granules, where present, lose their individuality, constituting an amorphous mass of acidofhilic substance. The appearance of an atretic follicle is that of a shapeless oocyte, presenting vacuoles and small yellowish flakes (Fig. 9). Atretic follicles may occur at any phase of the gonadal development.

The simultaneous presence of oocytes in different phases of development and of postovulatory follicles shows that the Argentine hake presents group synchronous oocytes development and multiple spawning.

On the basis of the above information, the following scale of gonadal maturation may be drawn up for the female of Merluccius hubbsi: 


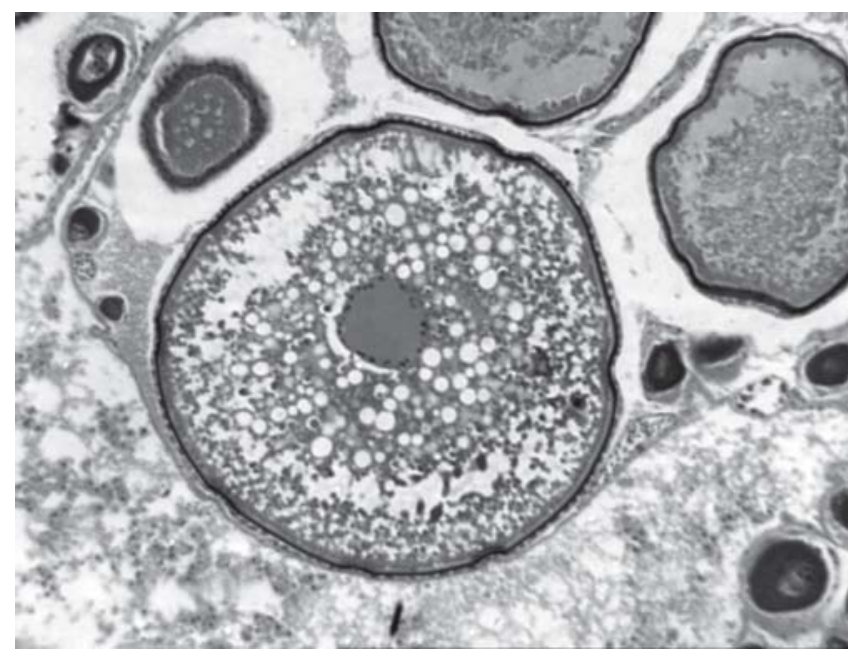

Fig. 6. Merluccius hubbsi: oocyte with complete vitellogenesis (1.5mm length field).

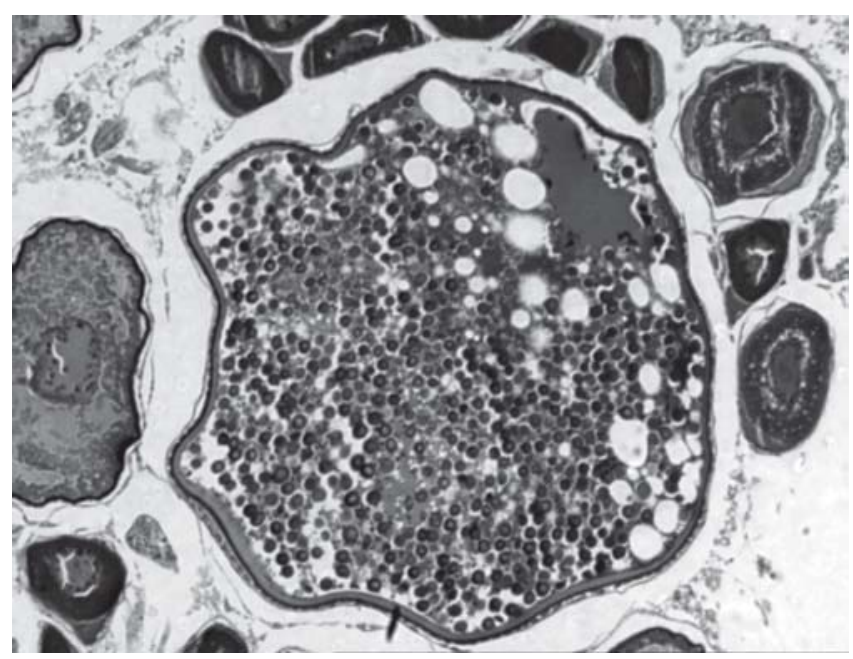

Fig. 7. Merluccius hubbsi: oocyte with nuclear migration (1.5mm length field).

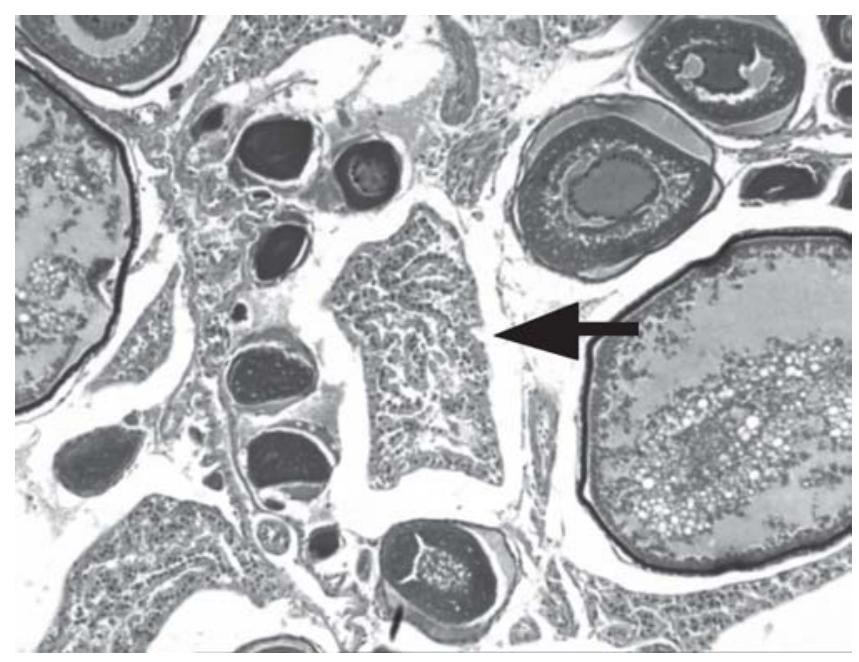

Fig. 8. Merluccius hubbsi: postovulatory follicle (arrow) (1.5mm length field).

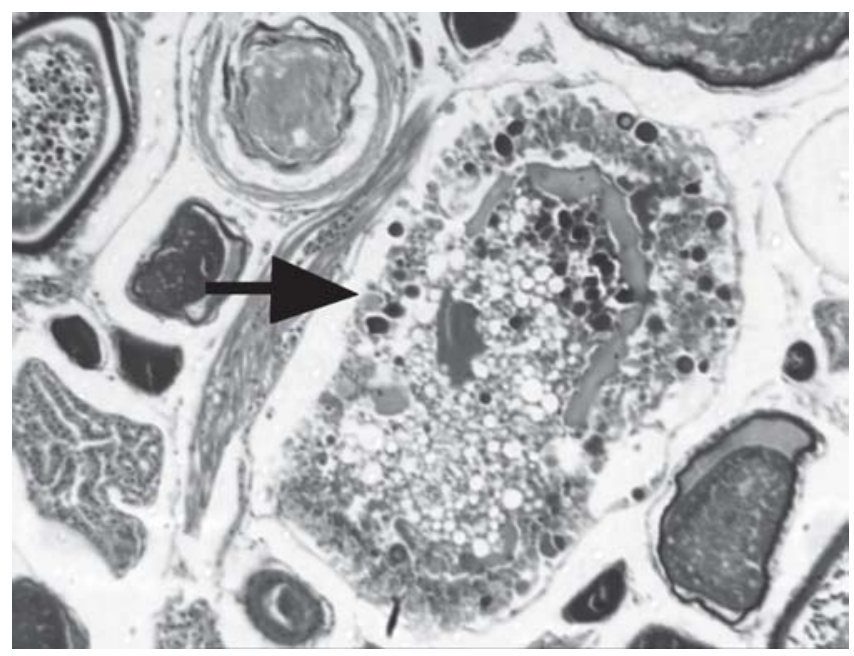

Fig. 9. Merluccius hubbsi: atresic follicle (arrow) (1.5mm length field).

A - immature - ovaries small and turgid, varying from translucent to yellowish-pink colour, with incipient blood irrigation; oocytes of phases I and II are present;

B - maturing - ovaries of different sizes, with a yellow colouring due to the presence of a majority of oocytes of phase III, as yet still not clearly individualised; blood irrigation is not noticeable;

C - mature - large, full ovaries taking up a large part of the abdominal cavity, mainly oocytes in phase IV, that one appearing as individualized cells, intense yellowish - orange colour, with a tendency to brown due to the quantity of vitello; intense vascularization;

D - spawning - the ovaries are large, with individualised and hydrated oocytes (phase V), with orange-yellow or dun colouring and granulous appearance. Between spawning intervals, the ovaries may present some flacidity due to the liberation of part of the oocytes; in this condition, despite the transition of the oocytes from phase IV to phase V, the presence of postovulatory follicles is already evident, being a sign of spawning;

E - spent - the ovaries present different degrees of flacidity, are haemorrhagic with reddish colour due to bleeding; some oocytes are still to be seen inside them, but old and recent postovulatory follicles predominate.

In the light of the histological analysis, the change in the classification of the ovaries initially undertaken is show in Fig. 10.

The comparison between macroscopic and microscopic identifications resulted in the following percentages of coincidence: immature $-94 \%$; maturing $-8 \%$; mature $-39 \%$ and spent $-16 \%$. In the case of those which were in the spawning phase, the use of the macroscopic scale without this category did not provide coincidence between the macroscopic and microscopic analyses. These results are summarized in Table 2. 


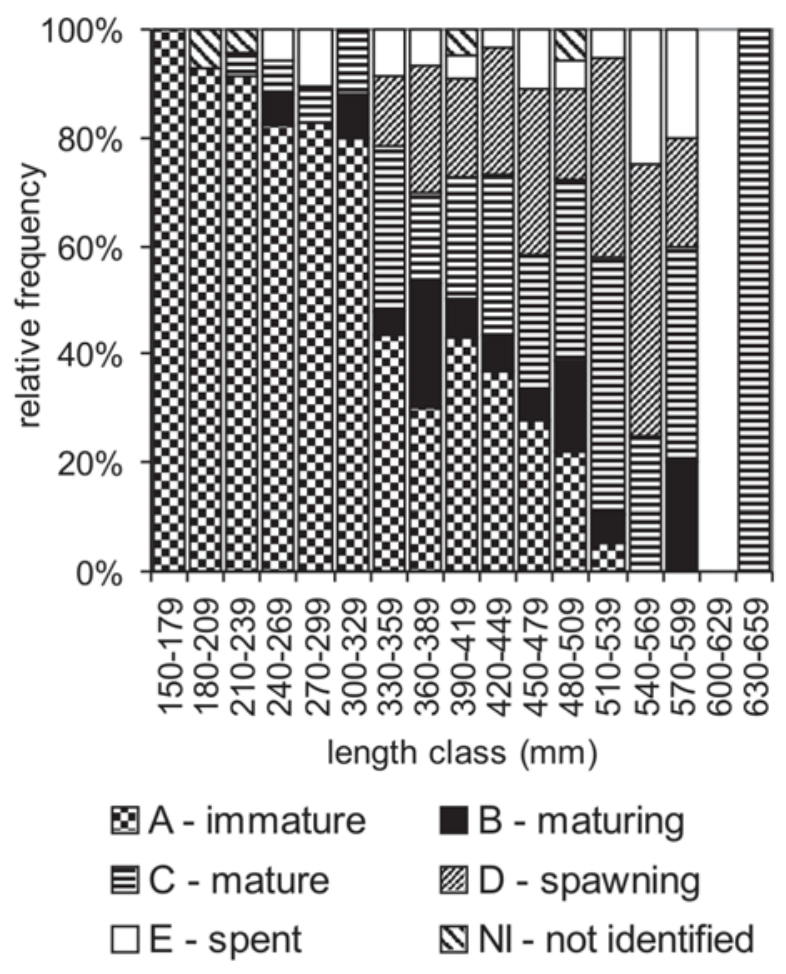

Fig. 10. Merluccius hubbsi: relative frequency of females by stage of gonadal maturation identified microscopically by class of total lenght $(n=326)$.

\section{Discussion}

The phases of oocyte development found in the Merluccius hubbsi of the Brazilian coast were similar to those described in the related literature, thus confirming the group synchronous development and multiple spawning registered for the Argentine hake (Angelescu et al., 1958; Ciechomski, 1967; Olivieri \& Christiansen, 1987; Louge, 1996; Cousseau \& Perrotta, 2004, Pájaro et al., 2005). The oocyte development of the Argentine hake presents the same kinds of oocytes described by Christiansen (1971), West (1990) and Vazzoler (1996) (Table 3), differing only in the grouping criterion of the development phases.

Thus, the differences found regarding to Christiansen's work (1971) are due to that author, who describes the development of the oocytes in association with macroscopic char- acteristics of the ovaries. On his part, West (1990) called phase $\mathrm{V}$ (mature) associating within it cells in complete vitellogenesis those with migrating nucleus and the hydrated ones. However, the migration of the nucleus and the hydration are events which occur some hours before spawning (Hunter \& Goldberg, 1980; Tyler \& Sumpter, 1996), and it is not therefore appropriate to associate them with complete vitellogenesis, seeing that the oocytes may remain ready for spawning for several days (Olivieri \& Christiansen, 1987).

The phases of oocyte development described by Vazzoler (1996) are to be found in the majority of teleosts. In this present study it was decided to group the oocytes with chromatinnucleolar and perinucleolar at the same group (phase I). The oocytes with chromatin-nucleolar are the most common in immature ovaries, whereas the perinucleolar oocytes are present in all the phases of oocyte development (Vazzoler op. cit.). Thus, in an immature ovary, two kinds of oocytes are to be found, which justifies the adopted procedure.

In relation to the maturation scales, the macroscopic identification undertaken a priori presented satisfactory results only for immature ovaries ( $94 \%$ agreement), a degree of success which may be attributed to the relative ease of identifying them, as they are typical of young females.

For all the other stages of maturation, the initial identification made were erroneous, with the least agreement $(8 \%)$ occurring with regard to the maturing stage, in which, in fact, $59 \%$ of the gonads were still immature. This results because of their yellowish-pink appearance and their volume, which, to the naked eye, suggest that the ovary is maturing. Dias et al. (1998) comparing the macroscopic and microscopic identification ovaries maturation of some teleosts, confirmed the results obtained, showing that the maturing stage is that which is subject to greatest discrepancy as regards classification. Otherwise, freezing could contribute to change ovaries appearance.

Concerning the mature females, the low percentage of correct classification (39\%) may be related to errors in the staging of females which present multiple spawning, a fact which was also reported by Herrera et al. (1988) for Merluccius gayi gayi and by West (1990) for others teleosts with this same reproductive strategy. Olivieri \& Christiansen (1987) estimated the liberation of oocytes of $M$. hubbsi as occurring at intervals of approximately 22 days. In this present study, $35 \%$ of the females had already spawned and were ready to

Table 2. Merluccius hubbsi: comparison between macroscopical and microscopical staging of ovarian development. Absolute values and percentages related to macroscopical identifications for agreement identifications are in bold type.

\begin{tabular}{|c|c|c|c|c|c|c|c|c|c|c|c|c|c|c|}
\hline \multirow{3}{*}{\multicolumn{2}{|c|}{$\begin{array}{l}\text { Stage of Gonadal } \\
\text { Development }\end{array}$}} & \multicolumn{12}{|c|}{ Microscopical identification } & \multirow{3}{*}{ Total } \\
\hline & & \multicolumn{2}{|c|}{ A } & \multicolumn{2}{|c|}{$\mathrm{B}$} & \multicolumn{2}{|c|}{$\mathrm{C}$} & \multicolumn{2}{|c|}{$\mathrm{D}$} & \multicolumn{2}{|c|}{$\mathrm{E}$} & \multicolumn{2}{|c|}{ NI } & \\
\hline & & $\mathrm{n}^{\circ}$ & $\%$ & $\mathrm{n}^{\circ}$ & $\%$ & $\mathrm{n}^{\circ}$ & $\%$ & $\mathrm{n}^{\circ}$ & $\%$ & $\mathrm{n}^{\circ}$ & $\%$ & $\mathrm{n}^{\circ}$ & $\%$ & \\
\hline \multirow{5}{*}{$\begin{array}{l}\text { Macroscopical } \\
\text { identification }\end{array}$} & $\mathrm{A}$ & 47 & 94 & 1 & 2 & & & & & 1 & 2 & 1 & 2 & 50 \\
\hline & B & 77 & 59 & 11 & 8 & 22 & 17 & 15 & 11 & 5 & 4 & 1 & 1 & 131 \\
\hline & $\mathrm{C}$ & 11 & 12 & 3 & 3 & 36 & 39 & 32 & 35 & 7 & 8 & 3 & 3 & 92 \\
\hline & D & 14 & 45 & 3 & 10 & 5 & 16 & 4 & 13 & 5 & 16 & & & 31 \\
\hline & NI & 11 & 50 & 5 & 23 & 4 & 18 & & & 2 & 9 & & & 22 \\
\hline Total & & 160 & & 23 & & 67 & & 51 & & 20 & & 5 & & 326 \\
\hline
\end{tabular}


liberate new batches of oocytes, thus being ready to spawn again. Another source of error is due to the impossibility of seeing the hydrated oocytes, which are easily modified by the freezing (no specimen was examined fresh) and oocytes with nuclear migration, which have to be examined microscopically to be identified.

The inclusion of resting females in the maturing stage (macroscopic staging) was not a problematic proceeding as the degree of discrepancy was only $4 \%$. However, a fact to be considered is the number of immature females (showed in the Figure 10) identified after the first length of maturation (356.80mm, according to Vaz-dos-Santos et al., 2005). This can be attributed to the impossibility in separating resting and immature ovaries within the analysed samples.

The facts presented show that the macroscopic scale of ovarian maturation used is not adequate for $M$. hubbsi, on account of the kind of spawning typical of the species (multiple) and of the subjectivity of the elements considered when obtained by the naked eye (colouring, size, etc). In the majority of cases, the various classifications of ovarian maturation stages available to $M$. hubbsi taken into consideration, beyond the morphological appearance of the gonads, the phases of oocyte development, these latter contributing to the reduction of errors. There are exceptions, however: the macroscopic scale used by Portela et al. (1994) for the Argentine hake contains only four stages of maturation of the gonads and does not consider the maturing stage, in which the greatest percentage of errors occurs, as the results of this present study and of that of Dias et al. (1998) show. Despite Portela et al.'s (op. cit.) justify the simplification of the scale as a way of reducing the number of errors, we consider its use inadequate.

The scale of ovarian maturation presented by Angelescu et al. (1958) for the Argentine hake of the Bonaerense sector (between $34^{\circ} \mathrm{S}$ and $41^{\circ} \mathrm{S}$, covering Uruguay, the River Plate estuary and the northern part of Argentina) was modified and enlarged by Christiansen \& Cousseau (1971), who, combining macro and microscopic characteristics and also using fish of the Patagonian sector (from south of $41^{\circ} \mathrm{S}$ ), proposed seven stages of maturation. This classification has not been adopted in this present study because it is based on fresh material, which is certainly a difficult procedure for marine fishes in Brazil. When one works with previously frozen ovaries, the differentiation between virgin and pre-mature virgin ovaries, an incipient blood irrigation (Christiansen \& Cousseau, 1971) is not clear and only allows their inclusion in the immature category. Further, the differentiation between initial and ad- vanced maturation and between maturing and resting ovaries is subjective, which is the reason for those categories were not being adopted in this present study.

In the same way, Louge \& Christiansen (1992) analysed the reproductive dynamic of $M$. hubbsi of the Patagonian sector, adding to Christiansen \& Cousseau's scale (1971) details on the diameter of oocytes, based on histological crosssections. These latter authors also drew attention to the different kinds of postovulatory follicles present in the ovaries, initially described by Olivieri \& Christiansen (1987) for the Argentine hake. In the material analysed the follicles identified did not present the characteristics described by Olivieri \& Christiansen (1987) and Cornejo (1998), which would permit their differentiation, due to the difficulty in characterizing them 24 hours after spawning (Hunter \& Goldberg, 1980; Hunter \& Leong, 1981).

Although this present study has not adopted the gonadal maturation scale used by Louge \& Christiansen (1992), the precision of the results obtained confirms the suggestion of those authors: to understand the Argentine hake reproduction it is necessary histological ovaries studies. The detailed, precise results on the reproduction of the Argentine hake obtained by Louge \& Christiansen (1993) and Louge (1996), which were also based on the histology of the ovaries, also bring out this need.

A scale of maturation with a small number of stages would make its use easier and minimize the number of errors of identification, even when histological techniques are applied. Narahara (1995) used a scale with few stages based on different development phases, which was clearly advantageous. This same recommendation is made by Dias et al. (1998).

Even though West (1990) states that histology is unnecessary for routines studies, the results of this present study clearly reflect the problems of the exclusive use of the macroscopic classification for the ovarian development of M. hubbsi. Despite its being simple and of immediate application, the macroscopic classification of ovaries reduce the value of the results based on it. Thus the procedure for the value estimation of the length of first maturation $\left(\mathrm{L}_{50}\right)$ involves the classification of females as young (immature) and adult (all the other stages of maturation). On the basis of the histology of ovaries, Vaz-dosSantos et al. (2005) estimated the $\mathrm{L}_{50}$ of the Argentine hake in the South-Southeast of Brazil as $356.80 \mathrm{~mm}$. If only a scale of microscopic maturation is used (Fig. 10), the value obtained is very similar (length class $330-380 \mathrm{~mm}$ ). However, if one uses only a macroscopic maturation scale (Fig. 2), the value stands

Table 3. Comparison between phases of oocyte development proposed in this paper and by other authors.

\begin{tabular}{lcccc}
\hline \multicolumn{1}{c}{ Oocyte Stage } & Present Study & Vazzoler, 1996 & West, 1990 & Christiansen, 1971 \\
\hline Chromatin Nucleolar & I & I & I & I \\
Perinucleolar & I & II & II & II \\
Cortical alveolar & II & III & III & II \\
Lipid and Proteic Vitellogenesis & III & IV & IV & III \\
Complete Vitellogenesis & IV & V & V & IV \\
Nuclear Migration & V & VI & V & V \\
Hydration & V & VI & V & V \\
\hline
\end{tabular}


in the length class $180-209 \mathrm{~mm}$. Concerning the stock management, the latter value presents a strong error with serious damage to larger part of the reproductive stock.

\section{Acknowledgements}

The authors wish to thank the Programa de Avaliação do Potencial Sustentável dos Recursos Vivos da Zona Econômica Exclusiva (REVIZEE) for their financial and logistic support of this project. We also wish to thank June Ferraz Dias, Instituto Oceanográfico da Universidade de São Paulo (IOUSP), and Luis Alberto Zavala-Camin, Universidade Santa Cecília (UNISANTA), for their teaching on and discussions of the theme. We also wish to thank Lucy Satiko Hashimoto Soares, of the Instituto Oceanográfico da Universidade de São Paulo (IOUSP), for permitting the use of material of the DEPROAS project. We express our gratitude to the Conselho Nacional de Pesquisa e Desenvolvimento $(\mathrm{CNPq})$ for the granting of the ITI scholarship to the first author (Process $n^{\circ}$ 180129/02-3). The second author thanks the research workers María Inés Lorenzo, of DINARA (Montevideo, Uruguay) and Susana Bezzi, of INIDEP (Mar del Plata, Argentina) and the librarians Gabriela Silvoni and Guillermina Cosulich of INIDEP for the valuable bibliography. We acknowledge the two anonymous referees that improved our study.

\section{Literature Cited}

Angelescu, V., F. S. Gneri \& A. Nani. 1958. La merluza del mar argentino: biología e taxonomía. Buenos Aires, Servicio de Hidrografía Naval, $225 \mathrm{p}$.

Aubone, A., S. I. Bezzi., R. Castrucci, C. Dato, P. Ibáñez, G. Irusta, M. Pérez, M. Renzi, B. Santos, N. Scarlato, M. Simonazzi, L. Tringali \& F. Villarino. 2000. Merluza (Merluccius hubbsi). Pp. 30-39. In: Bezzi, S.; R. Akselman \& E. E. Boschi (Eds.). Síntesis del estado de las pesquerías marítimas argentinas y de la Cuenca del Plata. Años 1997 - 1998, con la actualización de 1999. Mar del Plata, INIDEP, 388p.

Bezzi, S. I. \& P. Ibáñez. 2003. Estimaciones de la biomasa de la merluza (Merluccius hubbsi) entre 1994 y 1999 y características de la unidad de manejo norte $\left(34^{\circ} \mathrm{S}\right.$ a $\left.41^{\circ} \mathrm{S}\right)$. Frente Marítimo, 19: 47-56.

Bezzi, S. I., G. Irusta, P. Ibáñez, M. Simonazzi \& F. Castañeda. 2000a. La pesquería argentina de merluza (Merluccius hubbsi) en la Zona Común de Pesca. Período 1986-1996. Frente Marítimo, 18: 7-23.

Bezzi, S. I., G. Irusta, M. Simonazzi, R. Castrucci \& P. Ibáñez. 2000b. Sucesos biológicos y pesqueros del efectivo pesquero norte de merluza (Merluccius hubbsi) entre $39^{\circ} \mathrm{S}$ y $41^{\circ} \mathrm{S}$. Frente Marítimo, 18: 25-30.

Bezzi, S. I. \& L. Tringali. 2003. Áreas de reproducción y de crianza de la merluza (Merluccius hubbsi): antecedentes científicos y relación con su marco regulatorio en la República Argentina. Frente Marítimo, 19: 57-73.

Christiansen, H. E. 1971. Descripción histológica del ciclo del ovario de merluza. Boletín del Instituto de Biología Marina, Mar del Plata, 20: 3-41.

Christiansen, H. E., S. R. Brodsky \& M. E. Cabrera. 1973. La microscopia aplicada con criterio poblacional en el estudio de las gónadas de los vertebrados e invertebrados marinos. Physis, Sec. A, 32(85): 467-480.

Christiansen, H. E. \& M. B. Cousseau. 1971. La reproducción de la merluza y su relación con otros aspectos biológicos de la especie. Boletín del Instituto de Biología Marina, Mar del Plata, 20: 43-75.

Christiansen, H. E., P. D. Glorioso \& C. E. Olivieri. 1986. Aplicación de la histología en la determinación de los efectivos de merluza (Merluccius hubbsi). Tipificación de tejidos, cálculos de la fecundidad y vinculación con las condiciones ambientales. Publicaciones de la Comisión Técnica Mixta del Frente Marítimo, 1(2): 567-574.

Ciechomski, J. D. 1967. Carácter del desove y fecundidad de la merluza argentina, Merluccius merluccius hubbsi, del sector bonaerense. Boletín del Instituto de Biología Marina, Mar del Plata, 13: 1-30.

Cornejo, A. M. 1998. Descripción histológica de las fases de los folículos post-ovulatorios en ovarios de merluza común (Merluccius hubbsi). Revista de Biología Marina y Oceanografía 33(1): 89-99.

Cousseau, M. B. \& R. G. Perrotta. 2004. Peces marinos de Argentina: biología, distribución, pesca. Mar del Plata, INIDEP, $3^{\text {a }}$ ed, $167 \mathrm{p}$.

Dias, J. F., E. Peres-Rios, P. T. C. Chaves \& C. L. D. B. RossiWongtschowski. 1998. Análise macroscópica dos ovários de teleósteos: problemas de classificação e recomendações de procedimentos. Revista Brasileira de Biologia, 58(1): 55-69.

Figueiredo, J. L. \& N. A. Menezes. 1978. Manual de peixes marinhos do Sudeste do Brasil, vol II: Teleostei (1). São Paulo, Museu de Zoologia da Universidade de São Paulo, 110p.

Figueiredo, J. L., A. P. Santos, N. Yamaguti, R. A. Bernardes \& C. L. D. B. Rossi-Wongtschowski. 2002. Peixes da Zona Econômica Exclusiva da Região Sudeste-Sul do Brasil. São Paulo, Edusp, 242p.

Grier, H. 2000. Ovarian germinal epithelium and folliculogenesis in the Common Snook, Centropomus undecimalis (Teleostei: Centropomidae). Journal of Morphology 243: 265-281.

Grunwaldt, P. 1986. Contribución al conocimiento de la fecundidad y el carácter del desove de la merluza (Merluccius hubbsi). Publicaciones de la Comisión Técnica Mixta del Frente Marítimo, 1(1): 66-74.

Guerra, A. \& J. L. Sánchez. 1998. Fundamentos de explotación de recursos vivos marinos. Zaragoza, Editorial Acribia, 249p.

Haimovici, M., A. S. Martins \& E. R. L. Teixeira. 1993. Distribución, alimentación y observaciones sobre la reproducción de la merluza (Merluccius hubbsi) en el Sur de Brasil. Frente Marítimo,14: 3340.

Herrera, G., E. Bustos-Obregón \& F. Balbontín. 1988. Morphological aspects of gonadal maturation in the hake, Merluccius gayi gayi. Revista de Biología Marina, Valparaíso, 24(1): 55-71.

Hunter, J. R. \& S. R. Goldberg. 1980. Spawning incidence and batch fecundity in Northern anchovy, Engraulis mordax. Fishery Bulletin 77(3): 641-652.

Hunter, J. R. \& R. Leong. 1981. The spawning energetics of female northern anchovy, Engraulis mordax. Fishery Bulletin 79(2): 215-230.

Hunter, J. R. \& B. J. Macewicz. 1985. Rates of atresia in ovary of captive and wild northern anchovy, Engraulis mordax. Fishery Bulletin 83(2): 119-136.

Lorenzo, M. I. 2003. Crecimiento y mortalidad de la merluza en la Zona Común de Pesca Argentino-Uruguaya. Frente Marítimo, 19: 37-46.

Louge, E. B. 1996. Variaciones espacio-temporales del fenómeno reproductivo de la merluza Merluccius hubbsi Marini 1933 du- 
rante su concentración invernal en la Zona Común de Pesca Argentino-Uruguaya. Boletín del Instituto Español de Oceanografía, 11(2): 123-139.

Louge, E. B. \& H. E. Christiansen. 1992. Dinámica reproductiva de la merluza Merluccius hubbsi Marini, 1933, durante su concentración estival de 1988 en la Costa de Argentina. Biología Pesquera 21: 3-14.

Louge, E. B. \& H. E. Christiansen. 1993. Fecundidad de la merluza Merluccius hubbsi durante la temporada estival de 1988. Boletín del Instituto Español de Oceanografía, 9(2): 343-346.

Narahara, M. Y. 1995. Histofisiologia das gônadas de teleósteos. Jaboticabal, FUNEP/FCAVJ-UNESP: 11-25.

Olivieri, C. \& H. E. Christiansen. 1987. Consideraciones preliminares sobre la frecuencia reproductiva de la merluza común (Merluccius hubbsi). Publicaciones de la Comisión Técnica Mixta del Frente Marítimo, 3: 67-71.

Pájaro, M., G. Macchi \& P. Martos. 2005. Reproductive pattern of the Patagonian stock of Argentine hake (Merluccius hubbsi). Fisheries Research, 72: 97-108.

Patiño, R. \& C. V. Sullivan. 2002. Ovarian follicle growth, maturation and ovulation in teleost fish. Fish Physiology and Biochemistry 26: 57-70.

Portela, J. M., N. P. Contreras \& V. T. Gorbea. 1994. Aspectos reproductivos del calamarete (Loligo gahi), el calamar (Illex argentinus) y la merluza (Merluccius hubbsi) en el Atlántico Sudoccidental. Frente Marítimo, 15: 21-36.

Rey, M. \& G. Arena. 1999. Merluza (Merluccius hubbsi): estudios realizados dentro de la Zona Común de Pesca ArgentinoUruguaya en el marco del Plan de Investigación Pesquera. Montevideo, INAPE/PNUD, 211p.

Sabatini, M. E. 2004. Características ambientales, reproducción y alimentación de la merluza (Merluccius hubbsi) y la anchoíta (Engraulis anchoita) en su hábitat reproductivo patagónico: síntesis y perspectivas. Revista de Investigación y Desarrollo Pesquero 16: 5-25.
Torres-Pereira, I. G. 1983. Morfometria, caracteres merísticos, osteologia e alimentação dos estágios larvais e distribuição dos ovos e larvas de merluza, Merluccius hubbsi (Gadiformes: Merlucciidae) na plataforma continental do Rio Grande do Sul. Unpublished M.Sc. Dissertation, Fundação Universidade do Rio Grande (FURG), Rio Grande. 105p.

Tyler, C. R. \& J. P. Sumpter. 1996. Oocyte growth and development in teleosts. Reviews in Fish Biology and Fisheries 6: 287-318. Vaz-dos-Santos, A. M. 2002. Idade e crescimento da merluza Merluccius hubbsi Marini, 1933 (Teleostei: Merlucciidae) na Zona Econômica Exclusiva entre o Cabo de São Tomé (RJ) e o Chuí (RS), Brasil. Unpublished M.Sc. Dissertation, Instituto Oceanográfico da Universidade de São Paulo, São Paulo. 197p.

Vaz-dos-Santos, A. M., R. M. Honji \& C. L. D. B. RossiWongtschowski. 2005. Comprimento e idade de primeira maturação gonadal de fêmeas de merluza Merluccius hubbsi Marini, 1933 na Região Sudeste-Sul do Brasil. Boletim do Instituto de Pesca, São Paulo, 31(2): 109-117.

Vaz-dos-Santos, A. M. \& C. L. D. B. Rossi-Wongtschowski. 2005. Merluccius hubbsi Marini, 1933. Pp. 88-93. In: Cergole, M. C.; A. O. Ávila-da-Silva \& C. L. D. B. Rossi-Wongtschowski (Eds.). Análise das Principais Pescarias Comerciais da Região SudesteSul do Brasil: Dinâmica Populacional das Espécies em Explotação. São Paulo, IOUSP, 176p.

Vazzoler, A. E. A. de M. 1996. Biologia da Reprodução de Peixes Teleósteos: teoria e prática. Maringá, EDUEM, 169p.

West, G. 1990. Methods of assessing ovarian development in fishes: a review. Australian Journal of Marine and Freshwater Research, 41: 199-222.

Received January 2006 Accepted August 2006 